Journal of Biotechnology and Strategic Health Research

Olgu Sunumu / Case Report

http://dergipark.org.tr/tr/pub/bshr

\title{
İnsan Metapnömovirüs'e İnfluenza A Virüsünün Eşlik Ettiği 4.5 Aylık Süt Çocuğunda Alt Solunum Yolu Enfeksiyonu
}

\section{Lower Respiratory Tract Infection due to coinfection of Influenza A Virus and Human Metapneumovirus in A 4.5-Month-Old Infant With}

\section{Ayșegül Pala ${ }^{1}$, (D) $ه$ Öner Özdemir ${ }^{2}$}

${ }^{1}$ Çocuk Sağlığı ve Hast. ABD, Sakarya Üniversitesi Tip Fakültesi, Sakarya Üniversitesi Eğitim ve Araştırma Hastanesi, Sakarya ${ }^{2}$ Çocuk İmmünolojisi ve Alerji Hast. BD, Sakarya Üniversitesi Tip Fakültesi, Sakarya Üniversitesi Eğitim ve Araştırma Hastanesi, Sakarya ORCID ID: Ayşegül Pala 0000-0001-9056-144X, Öner Özdemir 0000-0002-5338-9561

*Sorumlu Yazar / Corresponding Author: Prof. Dr. Öner Özdemir, e-posta / e-mail: ozdemir_oner@hotmail.com Geliș Tarihi / Received : 04-04-2020 Kabul Tarihi / Accepted: 18-04-2020 Yayın Tarihi / Online Published: 30-042020

Atıf Gösterimi/How to Cite: GPala A., Özdemir Ö. İnsan Metapnömovirüs’e İnfluenza A Virüsünün Eşlik Ettiği 4.5 Aylık Süt Çocuğunda Alt Solunum Yolu Enfeksiyonu, J Biotechnol and Strategic Health Res. 2020;4(1):67-71

$\ddot{O} z$

Alt solunum yolu enfeksiyonları (ASYE) çoğunlukla respiratuvar sinsisyal virüs (RSV), influenza, parainfluenza, rhinovirüs ve adenovirüs kaynaklıdır. Ancak, son yıllarda bu virüslere ek olarak insan metapnömovirüs (iMPV), parainfluenza 4 ve bocavirüs gibi virüslerinde ASYE’ye sebep olduğu gösterilmiştir. Çocukluk çağında birden fazla virüsün ko-enfeksiyonu ile bronşiolit geliştiği unutulmamalıdır. Bu çalışmamızda, ateş ve öksürük şikâyeti ile hastanemize başvuran 4.5 aylık erkek bir bebekte iki farklı virüsün (iMPV ve influenza A) ko-enfeksiyonu sonucu gelişen bronşiolit olgusu sunuldu.

Anahtar human metapnömovirüs, infleunza A, koenfeksiyon, bronşiolit

Kelimeler

Abstract

Lower respiratory tract infections (LRTI) are mostly caused by respiratory syncytial virus (RSV), influenza, parainfluenza, rhinovirus and adenovirus. In recent years human other viruses such as human metapneumovirus (hMPV), parainfluenza 4 and bocavirus also have been reported to cause LRTI. Coinfection of more than one virus in childhood can develop bronchiolitis in children. In this study, we report a case of bronchiolitis developed by coinfection of hMPV and influenza A viruses in a 4.5-month-old male baby who admitted to our hospital with the fever and cough.

Keywords human metapneumovirus, influenza A, coinfection, bronchiolitis 


\section{GIIRIŞ}

Alt solunum yolu enfeksiyonları (ASYE) çocuk hastalarda morbidite ve mortalitenin majör nedenlerinden biridir. Bunların klinik tablosunda ateş, öksürük, hırıltılı solunum, bronşiolit, astım, krup, pnömoni görülür. ${ }^{1}$ Respiratuvar sinsisyal virüs (RSV), influenza $A / B$, parainfluenza $1 / 2 / 3$, rinovirüs ve adenovirüsler klasik solunum yolu enfeksiyonlarına yol açan yaygın virüsler olarak bilinirler. Ancak son yllarda ASYE ajanları üzerinde yapılan çalışmalardaki gelişmelere bağlı olarak insan metapnömovirüs (iMPV), coronavirüs, parainfluenza 4 , parvovirüs tip $4 / 5$, poliyomavirüs, insan bocavirüs gibi virüsleri tespit edilmiştir. $^{2}$

İnsan metapnömovirüs ilk olarak 2001 yllında Hollanda’da keşfedilmiş olup tek zincirli RNA virüsüdür. Paramyxoviridae ailesinden olup genelde adenovirüs ve influenza gibi virüslerle beraber enfekte eder ama bu durum klinik durumu ağırlaştırmaz. ASYE’nin çocuk hastalardaki yaygın sebebidir ve genelde 2 yaş altı çocuklarda görülür. Zayıf immün sistemi ve akciğer hastalıkları olan hastalarda risk yüksektir. Enfekte hastaların salgılarıla temas sonucu yayılır ve bronşiolit, pnömoni ve astım atakları gibi klinik komplikasyonlara yol açar. ${ }^{3}$

Bu çalışmamızda, ateş ve öksürük şikâyeti ile hastanemize başvuran 4.5 aylık erkek bir bebekte iki farklı virüsün (IMPV ve İnfluenza A) ko-enfeksiyonu sonucu gelişen bronşiolitin tedavisi ve İMPV ile ilgili güncel bilgileri tartışmayı amaçladık.

\section{OLGU}

Dört buçuk aylık erkek hasta yaklaşık 1 aydır devam eden öksürük, hırıltı nedeniyle akut bronşiolit ön tanısı almış ve salbutamol inhaler tedavisi başlanmıştı. Ancak bir hafta boyunca 38 dereceyi bulan ateşin eşlik etmesi üzerine tedavisine antibiyotik eklenmiştir. Kontrol için diş merkez polikliniğine başvuran hastaya alerjik bronşit şüphesiyle tedavisine alerji ilaçları eklenmişti. Şikayetlerinde artma olan hastanın yatışı yapıldı ve ateş: $36.4^{\circ} \mathrm{C}$, nabız: 121 , so- lunum sayısı: 40, SpO2: 94 ölçüldü. Aktif olarak sadece öksürük mevcuttu. Fizik muayenesinde dinlemekle akciğerleri bilateral yaygın ronküsler dışında diğer sistemik muayenesi normaldi. WBC: $5.630 \mathrm{~K} / \mathrm{uL}, \mathrm{HGB}: 10.6 \mathrm{~g} / \mathrm{dL}$, NEU: 690 K/uL, EOS: 323 K/Ul, PLT: 326.000 K/uL, CRP: $3 \mathrm{mg} / \mathrm{L}$ olan hastadan bakteriyel ve viral solunum paneli çalışıldı. Postero-anterior (PA) akciğer grafisinde kostalarda düzleşme gözlendi (Resim 1). Hasta İMPV ve İnfluenza A pozitif olduğu tespit edilince tedavisi salbutamol, ipratropium bromür, oseltamivir ve nazal irrigasyon olarak düzenlendi.

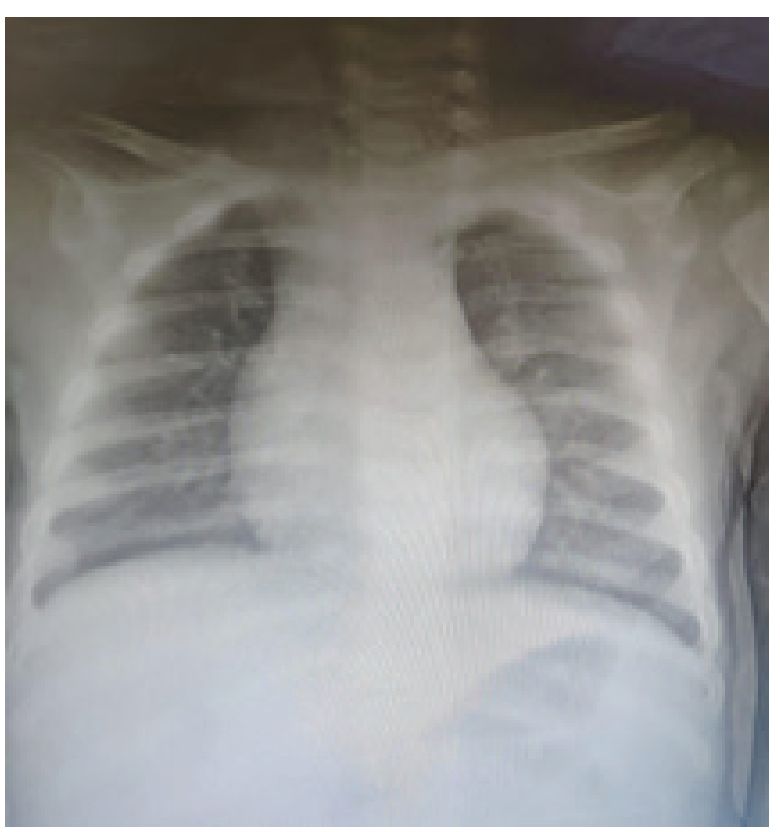

Resim 1: PA-akciğer grafisinde kostalarda düzleşme

Yatışının 3. gününde öksürük, ses kısıklı̆ğı, huzursuzluk gözlendi. Akciğerde bilateral yaygın krepitan ral ve ronküsleri vardı. Laboratuvar bulgular1 SpO2:\%92-94, ateş:38 ${ }^{\circ} \mathrm{C}$, WBC: $8.006 \mathrm{~K} / \mathrm{uL}, \mathrm{HGB}: 10.8 \mathrm{~g} / \mathrm{dL}$, NEU:2345 K/uL, EOS:72 K/Ul, PLT:232200 K/uL, CRP:23.6 mg/L, lgG: 7.6 g/L, Total lgE: <17.2 IU/Ml, lgM: 1.1 g/L, lgA: 0.12 $\mathrm{g} / \mathrm{L}$ idi. Kan kültüründe üreme olmadi. Kontrol PA akciğer grafisinde sağ akciğerde havalanma artı̧̧ı, sol akciğerinde ise infiltrasyon artışı mevcuttur (Resim 2). Tedavisine ek olarak oral klaritromisin $(15 \mathrm{mg} / \mathrm{kg} / \mathrm{gün})$ ve parenteral Sulbaktam-Ampisilin (100 mg/kg/gün) eklendi. Beslen- 
mesi azalan hastanın oral alımı kesildi ve idame sıvı verilmesine geçildi. Takiplerinde oksijensiz SpO2:\%88, oksijenli SpO2:\%94 olarak seyretti. Tedavisinde salbutamol ve ipratropium bromür günlük doz sayısı arttırıldı, sistemik steroit (2 mg/kg/gün) tedavisi ve oksijen desteği (6 lt/dk) başlandı. İlerleyen günlerde hastanın genel durumu iyi, öksürükleri azalmış, ateşi yok, SpO2'si oksijenli \%98, oksijensiz \%94 idi. Tedavisinde salbutamol ve ipratropium dozu azaltıldı, steroid ( $1 \mathrm{mg} / \mathrm{kg} /$ gün) tedavisi şeklinde düzenlendi. Takiplerinde genel durumu iyi, SpO2:\%96, akciğerleri dinlemekle bilateral eşit havalanması üzere tedavisi kesilerek taburcu edildi.

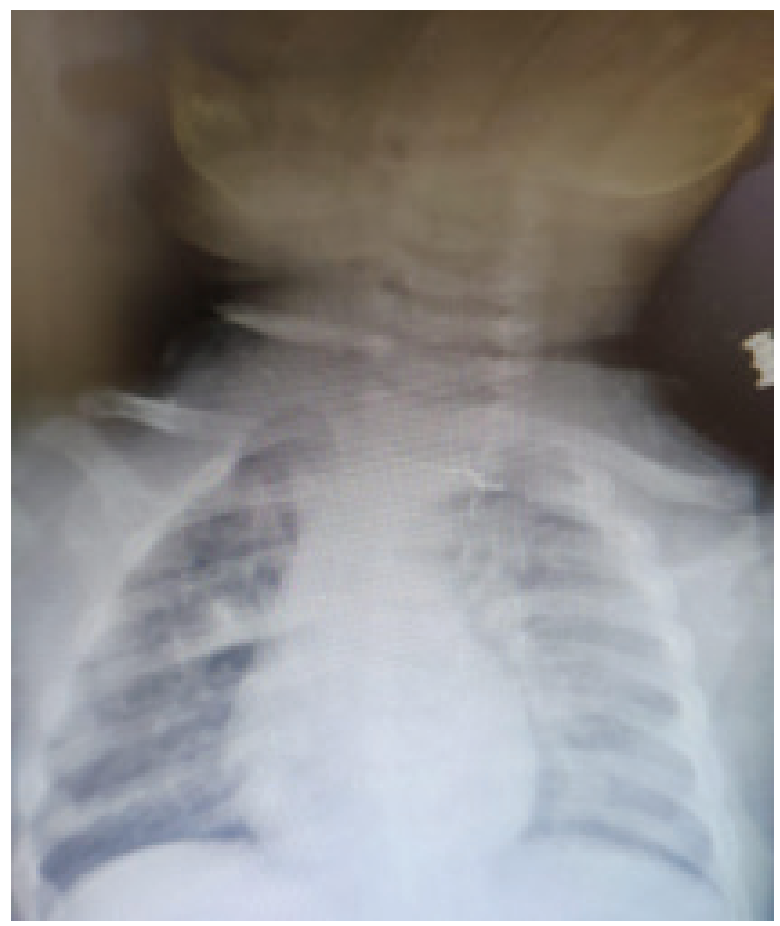

Resim 2: PA-akciğer grafisinde kostalarda düzleşme ve infiltrasyon artışı

\section{TARTIŞMA}

İnsan metapnömovirüs salgınları Ocak ile Mart ayları arasında görülür. Respiratuvar sinsisyal virüs ve influenza virüsleri gibi solunum yolları salgılarına temas sonucu kişiden kişiye geçer. Klinik tablosu öksürük, ateş hırıltılı solunum ve astım atak gibi durumlardan bronşiolit, pnömoni gibi hastalıklara kadar ilerleyebilir. Tanısı için viral hücre kültürleri kullanılır ancak hücre kültürünün analizi 2 hafta sürdügünden ve hassaslığı çok yüksek olmadığından genelde tercih edilmez. RT-PCR ise hücre kültürüne göre hem daha hızlı hem de daha hassas bir teknik olup IMPV tanısı için en yoğun kullanılan tekniktir. İnsan metapnömovirüs için spesifik antiviral ajan bulunmamakla beraber son yıllarda siRNA ve monoklonal antikor gibi terapötik üzerinde çalışılmaktadır. ${ }^{4,5}$ İnsan metapnömovirüs enfeksiyonlarının göğüs grafilerinde efüzyonlar veya lobar konsolidasyon olmaksızın perihiler opasiteler ve hiperinflasyon bulguları çok yaygındır. ${ }^{6}$ Hastamızda yaklaşık 1 aydır devam eden öksürük ve son günlerde ateş hikayesi de mevcuttu. Uzamış akut bronşiolit ön tanısıyla serviste tedavi altındayken, viral solunum paneli sonucunda hastada İMPV ve İnfluenza A pozitif olarak bulunmuştur.

İnfluenza virüsleri RNA virüsleri olup Ortomiksovirüs ailesine dahildirler. İnsanlarda influenza enfeksiyonuna çoğunlukla influenza A ve B, nadiren de C olmak üzere üç tip neden olur. Tip A ise üzerindeki hemaglütinin ve nöraminidaz proteinlere bak1larak H1N1, H2N2 ve H3N2 üç alt tipe ayrılır. İnfluenza enfeksiyonu çocuklarda genelde akut başlar ve hafif geçer ancak ciddi durumlarda morbidite ve mortalite ile ilişkilendirilebilir. Influenza virüslerinin en yüksek aktivitesi kış aylarında görülür ancak mevsimsel aktiviteleri genelde güz ve kış aylarıdır. Yayılma yolu damlacık şeklinde olup ortalama inkübasyon süresi iki gündür. Alt ve üst solunum yolu enfeksiyonları semptomları yaygın görülen klinik tablodur. 2 yaş altı çocuklarda pnömoni daha sık görülür. Diğer görülen solunum yolu komplikasyonları ise astım, laringotrakeit ve kruptur. İnfluenza enfeksiyonun tanısı için RT-PCR, hızlı moleküler assay, antijen testleri gibi teknikler kullanılır. RT-PCR teknikleri yüksek hassasiyet gösterir ancak her laboratuvarda bulunmayabilir. Hızlı moleküler teknikler ise yarım saat gibi bir sürede sonuç verip duyarlılıkları da yüksektir. Viral kültürler geç sonuç verdiğinden ilk aşamada önerilmez. Hızlı tanı antiviral tedavinin başlanmasını ve gereksiz antibiyotik kullanımını engeller. ${ }^{5,7}$ 
İnsan metapnömovirüs ve diğer patojenlerin koenfeksiyonu solunum yolları enfeksiyonunda sıklıkla görülen bir durumdur. İnsan metapnömovirüs'ün Streptococcus pneumoniae, Mycoplasma pneumoniae ve Chlamydia pneumoniae gibi bakteriyel ve coronavirüs gibi viral patojenlerle birlikteliği toplum kaynaklı pnömoni vakalarında gösterilmiştir. ${ }^{8}$ Brezilyảda yapılan bir çalışmaya göre gerçek-zamanlı PCR tekniği ile iMPV ve insan bocavirüs birlikteliğinin akut solunum yolları enfeksiyonunda sık olduğu gösterilmiştir. İran'da yapılan benzer bir çalışmada çocuk solunum yolu enfeksiyonunda, iMPV ve RSV koenfeksiyonun özellikle 1 yaş altı çocuklarda yaygın olduğu bildirilmiştir. ${ }^{10}$ Mizuta ve arkadaşları bir çalışmada iMPV enfeksiyonunun, RSV ve influenza mevsimsel vakalarını takiben Mart ve Nisan aylarında zirve yaptığı gösterilmiştir. ${ }^{11}$ Bosis ve arkadaşlarının çocukluklardan aldığı nazofaringeal sürüntüden 42 iMPV enfeksiyonun l'inde RSV ve 6’sında influenza virüsü tespit etmişlerdir. ${ }^{12}$ Lin ve arkadaşları çocuklardan aldıkları nazofaringeal aspirat örneklerin kültüründe İMP'nin influenza A ve parainfluenza tip 3 ile koenfeksiyonunu tespit etmişlerdir. ${ }^{13}$ Başka bir çalışmada, iMPV ve influenza tip B koenfeksiyonunun bağışıklık sistemi zayıf hastalarda ölümcül olduğu -bildirilmiştir. ${ }^{14}$ İnsan metapnömovirüsüun diğer patojenlerle koenfeksiyonu yaygın olmasına rağmen bu durumun İMPV kliniğini ağırlaştırdığına dair herhangi bir bulgu yoktur.

Olgumuzun nazal sürüntünün kültür analizinde, iMPV ve influenza A üremesi pozitif saptandı. Kış aylarında influenza enfeksiyonlarının pik yapması ve iMPV salgınlarının da bu dönemde yaygın olmasının hastamızda konenfeksiyona neden olduğunu düşünüyoruz. iMPV ve influenza A koenfeksiyonu gelişen hastamıza oseltamivir tedavisi başlanarak viral yayılımın önüne geçilmiştir.

Önceki makalemizde de belirttiğimiz gibi², iMPV enfeksiyonu her zaman kendi başına enfeksiyon yapmasa da; uzun süren bronşiolit, tekrarlayan wheezing (hışıltı) tanısı olan çocuklarda tek başına ya da koenfeksiyon şeklinde karşımıza çıkabileceği akılda tutulmalıdır. İnfluenza A en- feksiyonuna zemin mi hazırladığı ya da uzun süren alt solunum yolu enfeksiyonunun her iki virüsün yerleşmesine mi yol açtı̆̆ı günümüzde netliğe kavuşmamıştır.

Sonuç olarak, süt çocuğu bronşiolit tablosunda klasik virüslerin yanında insan metapnömovirüs enfeksiyonu göz ardı göz ardı edilmemeli ve hastalığın seyri ağırlaşmadan hızlı tanı teknikleri doğru tanısı konulup uygun tedavisi yapılmalıdır. 
J Biotechnol and Strategic Health Res. 2020;4(1):67-71

PALA, ÖZDEMİR, Metapnömovirüs ve İnfluenza A virüsünün Koenfeksiyonu

\section{Kaynaklar}

1. Pavia AT. Viral infections of the lower respiratory tract: old viruses, new viruses, and the role of diagnosis. Clin Infect Dis. 2011;52 Suppl 4:S284-9.

2. Ozdemir O, Bircan O. Human Metapneumovirus Infection in a Patient with Recurrent Wheezing: Case Report. Istanbul Medical Journal, 2019;20:p. 261-263.

3. Vinci A., Lee PJ, Krilov LR. Human Metapneumovirus Infection. Pediatrics in Review. 2018;39(12): p. 623.

4. Simon A, Manoha C, Müller A, et al. Human Metapneumovirus and Its Role in Childhood Respiratory Infections. Current Pediatrics Reports, 2014;2(3): p. 156-165.

5. Kayıran SM, Ercin S, Kaytran PG, et al. A case of pneumonia due to co-infection with two different viruses. The Medical Bulletin of Sisli Etfal Hospital, 2017;51(4): p. 342-345.

6. Hilmes MA, Daniel Dunnavant F, Singh SP, et al. Chest radiographic features of human metapneumovirus infection in pediatric patients. Pediatr Radiol. 2017;47(13):1745-1750.

7. Munoz FM. Seasonal influenza in children: Clinical features and diagnosis. In Mallory GB, Edwards, MS (eds). UpToDate Inc. https://www.uptodate.com/contents/seasonal-influenza-in-children-clinical-features-and-diagnosis (Accessed on January 13, 2020.)

8. Esposito S, Daleno C, Prunotto G, et al. Impact of viral infections in children with community-acquired pneumonia: results of a study of 17 respiratory viruses. Influenza Other Respir Viruses. 2013;7(1):18-26

9. Pilger DA, Cantarelli VV, Amantea SL, et al. Detection of human bocavirus and human metapneumovirus by real-time PCR from patients with respiratory symptoms in Southern Brazil. Memórias do Instituto Oswaldo Cruz. 2011;106: p. 56-60.
10. Parsania M, Poopak B, Pouriayevali MH, et al. Detection of Human Metapneumovirus and Respiratory Syncytial Virus by Real-Time Polymerase Chain Reaction Among Hospitalized Young Children in Iran. Jundishapur J Microbiol. 2016; 9(3): e32974. doi: 10.5812/ jjm.32974.

11. Mizuta K, Abiko C, Aoki Y, et al. Seasonal Patterns of Respiratory Syncytial Virus, Influenza A Virus, Human Metapneumovirus, and Parainfluenza Virus Type 3 Infections on the Basis of Virus Isolation Data between 2004 and 2011 in Yamagata, Japan. Japanese Journal of Infectious Diseases. 2013;66(2):p. 140-145.

12. Bosis S, Esposito S, Niesters HG, et al. Impact of human metapneumovirus in childhood: comparison with respiratory syncytial virus and influenza viruses. J Med Virol. 2005;75(1):p. 101-4.

13. Lin TY, Huang YC, Tsao KC, et al. Human metapneumovirus and community-acquired pneumonia in children. Chang Gung Med J. 2005;28:p. 683-8.

14. Ghattas C, Mossad SB. Fatal human metapneumovirus and influenza B virus coinfection in an allogeneic hematopoietic stem cell transplant recipient. Transpl Infect Dis. 2012;14(5):e41-3. doi: 10.1111/j.1399-3062.2012.00766.x. 